\title{
Risk assessment and economic appraisal of protection methods for the Tarascon-Arles railway embankment
}

\author{
Mark Cheetham ${ }^{1, a}$, Remy Tourment ${ }^{2}$ and Philippe Pelt ${ }^{3}$ \\ ${ }^{1}$ SNCF Réseau, Engineering Department, 6 avenue François Mitterrand, 93574 La Plaine St Denis \\ ${ }^{2}$ Irstea, Hydraulic Structures Research Unit, Irstea, Aix-en-Provence, France \\ ${ }^{3}$ SYSTRA, Programme Manager, Systra, Marseille, France
}

\begin{abstract}
The coordination of flood management practices and the reduction of flood risk as proposed under the Plan Rhône project has led to a vast program of flood defence modernization and construction in the lower Rhône valley. One key element of the project involves the construction of a new $9 \mathrm{~km}$ levee structure parallel to an existing railway line between the towns of Tarascon and Arles (Bouches-du-Rhône, France) on the left bank of the Rhône, which has historically been an obstacle to the propagation of flood flows. The new levee is designed to protect the towns of Arles and Tarascon up to the $10^{-2}$ annual probability flood event, after which floodwater will flow over a $5 \mathrm{~km}$ spillway which will be integrated into the structure. In case of overtopping of the spillway via a spillway structure, floodwater is collected in the space between the two embankments and will subsequently flow towards one of ten newly constructed flood discharge structures, spaced at regular intervals in the railway embankment. The levee will form part of a global system of defence which is designed against flooding on the Rhône with an annual probability of occurrence of $10^{-3}$. In the event of overtopping of the levee, the railway embankment will be subjected to hydraulic loading and is at risk of damage from flood flows. During the detailed design phase of the project, options were explored for optimizing the permanent protection for the railway embankment. Using results from $2 \mathrm{D}$ and $3 \mathrm{D}$ hydraulic numerical modelling, a detailed risk assessment of the railway embankment was undertaken to evaluate its vulnerability under different hydraulic loading conditions and for different failure mechanisms using various parameters including water depth, hydraulic load, the duration of flood exposure and flow velocity. A comprehensive understanding of the main mechanisms of embankment damage under hydraulic loading (internal/ external erosion, overtopping, rotational failure etc.), existing geotechnical conditions and the railway embankment structure were required to undertake the risk assessment. For each hydraulic loading scenario, a detailed economic appraisal was undertaken for each method of protection involving the evaluation of damages associated with disruption to train services and the associated costs to repair the structure. The final stage of the project involved integrating the economic assessment into a wider reaching multi-criteria analysis including indicators for train security, maintainability and environmental impact aspects. The multi-criteria approach was tested under two management strategies to evaluate the effectiveness of each embankment protection system. This paper outlines how the risk assessment, economic appraisal and management-strategy based multi-criteria approach resulted in a highly optimized system of embankment protection with significant gains in terms of both reduced cost of implementation and environmental enhancement whilst maintaining the high levels of railway security required by SNCF-RESEAU.
\end{abstract}

\section{Introduction}

This paper presents the work undertaken by SNCF Réseau in collaboration with Irstea and Systra to determine appropriate methods for protecting the railway line between the towns of Tarascon and Arles following the construction of a new levee and flood discharge structures in the railway embankment itself. The $150 \mathrm{M} €$ project will see the communities of Tarascon and Arles protected from flooding of the Rhône up to a flood with annual probability $10^{-2}$ with the larger conurbations

a Corresponding author: mark.cheetham@reseau.sncf.fr protected up to floods with an annual probability of occurrence of $10^{-3}$. Using an innovative approach to flood risk management, SNCF Réseau developed a Multicriteria decision making tool, allowing the railway infrastructure manager to identify suitably adapted methods of protecting the railway line from flooding under different management strategies. 


\section{Context}

\subsection{Characteristics of the railway line}

The railway embankment between the towns of Arles and Tarascon (Département of Bouches-du-Rhône) lies on the main line between Paris and Marseille (L830, see Figure 1).

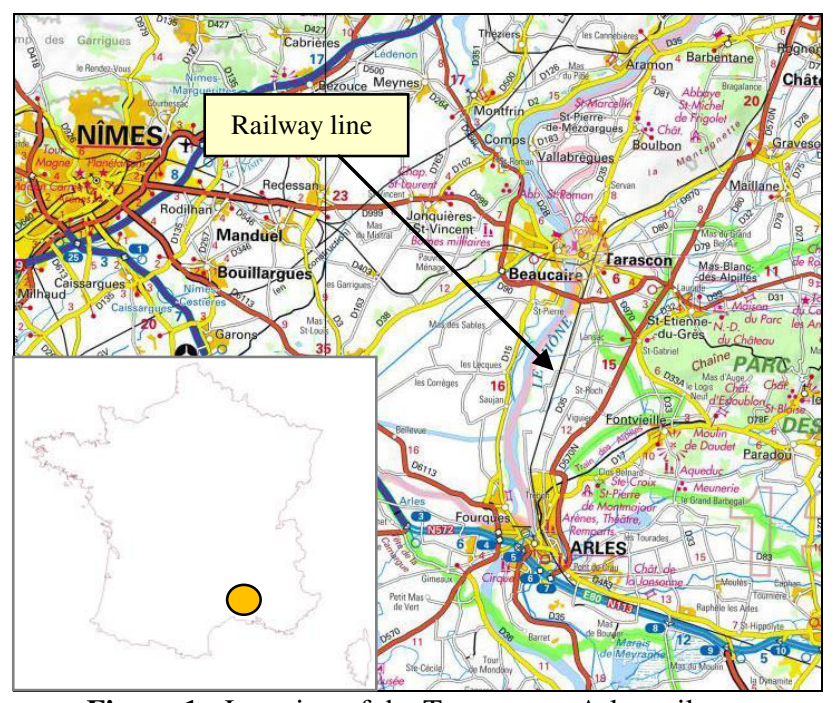

Figure 1 - Location of the Tarascon to Arles railway embankment $^{1}$

The line was constructed in the middle of the $19^{\text {th }}$ century through the excavation of material from 'borrow pits' adjacent to the line, which are still visible today. The embankment currently supports two tracks over which circulate approximately 200 trains per day. Train speed on the embankment is limited to $200 \mathrm{~km} / \mathrm{h}$.

In terms of its geometry, the embankment is $5 \mathrm{~m}$ in height on average and measures $15 \mathrm{~m}$ in width at crest level and, with bank slopes of $3 \mathrm{H} / 2 \mathrm{~V}$, approximately $30 \mathrm{~m}$ at ground level (see Figure 2). The line is electrified and the track structure is constructed on a ballast bed.

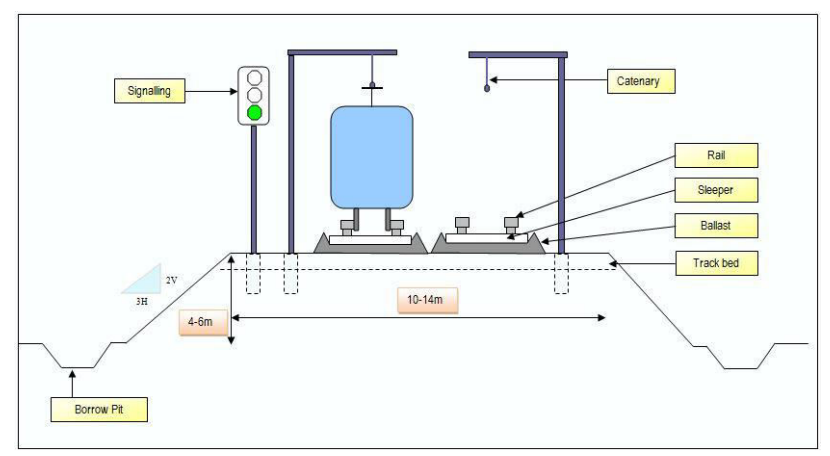

Figure 2 - Configuration of the railway embankment

Two hydraulic sluice structures are located in the railway embankment, which allow a drainage and irrigation canal (Lône du Castelet and the Canal des Alpines) to pass from the east side of the line to the Rhône on the west.
The River Rhône lies approximately $1 \mathrm{~km}$ to the west of the railway embankment. During periods of flooding on the Rhône, the sluice gates can be closed manually to prevent flood waters from flowing into the floodplain east of the railway line.

In the $1980 \mathrm{~s}$, a project was undertaken to increase train speed on the embankment up to the current limit of $200 \mathrm{~km} / \mathrm{h}$. During the project, a number of road-railway crossings were removed and replaced with structures beneath the line (road underpasses). The three new underpasses were in turn protected from floodwater from the Rhône by the construction of new earth embankments to the same height as the railway.

\subsection{Characteristics of the Rhône Catchment}

The River Rhône, with a length of approximately $780 \mathrm{~km}$ from its source at the Rhône Glacier in Switzerland to the city of Arles, drains a catchment with an area of approximately $95000 \mathrm{~km}^{2}$.

The peak discharge values at Tarascon for floods on the Rhône are presented in Table 1 . These values were evaluated during the project "Rhône Global Study" from flow data recordings at the Beaucaire/ Tarascon gauging station for the period of 1920 to 1998 (SAFEGE CETIIS, 2003).

\begin{tabular}{|c|c||}
\hline $\begin{array}{c}\text { Return period } \\
\text { (years) }\end{array}$ & $\begin{array}{c}\text { Peak discharge } \\
\left(\mathbf{m}^{\mathbf{3}} \mathbf{s}\right)\end{array}$ \\
\hline 2 & 6060 \\
\hline 5 & 7460 \\
\hline 10 & 8390 \\
\hline 50 & 10440 \\
\hline 100 & 11300 \\
\hline 500 & 13300 \\
\hline 1000 & 14160 \\
\hline
\end{tabular}

Table 1 - Return period peak flows for the Rhône at Tarascon

Numerous important flood events have affected the downstream reach of the river, the floods of reference being the event of 1840 with an estimated peak flow of $13000 \mathrm{~m}^{3} / \mathrm{s}$ and 1856 with a peak flow of $12500 \mathrm{~m}^{3} / \mathrm{s}$ at Tarascon (SOGREAH, 2006).

The 1840 event resulted in numerous breaches occurring in the flood defence system on the left bank notably in the levee "digue de la Montagnette" immediately upstream of Tarascon on the left bank and in the defences on the right bank at the site south of Beaucaire now known as the 'horseshoe' (the flood defence having been reconstructed around the breach zone in the shape of a horseshoe). The total length of breaches associated with the 1840 event was approximately $1 \mathrm{~km}(600 \mathrm{~m}$ on the left bank, $400 \mathrm{~m}$ on the right bank). 
The 1856 event created two breaches with a cumulative length of approximately $400 \mathrm{~m}$ in the "digue de la Montagnette". The 1840 and 1856 events are estimated to have had return periods of 500 years and 250 years respectively.

Further significant flooding occurred on two occasions in the downstream reach of the Rhône River catchment in October 1993 then again in January 1994 resulting in numerous breaches at various locations in the defence system along the Petit Rhône. Post-flood inspections of the levees concluded that all of the breaches were attributed to the process of internal erosion (Bonnefoy/ Royet, 1994).

In more recent times, two major floods have occurred namely 2002 and the event of December 2003, which had a return period of approximately 100 years (Consensus Conference, 2005 ${ }^{l}$ ) and which caused approximately $700 \mathrm{M} €$ of damages in the Rhône delta region. Breaches occurred in the defence system on the left bank between Arles and Tarascon, notably in two of the earth embankments protecting the underpass structures beneath the railway line. These two breaches resulted in floodwaters flowing through the underpasses and led to widespread flooding of the area to the east of the railway, including the north of the city of Arles and, to a lesser extent, some areas in the south of the city of Tarascon. The flooding with depths of up to several metres took over three weeks to subside causing widespread damage to a large number of residential and commercial properties in the town of Arles.

It should be noted that the railway embankment itself has never suffered a breach since its construction over 150 years ago.

\subsection{Description of the project}

Following the 2003 flood, the railway embankment received special status as having a role of flood defence, although it was not formally registered as a levee structure under French national law. This special status requires SNCF Réseau to undertake a number of visits including an annual detailed condition survey and a comprehensive risk analysis study to evaluate the level of security offered by the embankment.

With a view to reducing the exposure to flood risk for the communities in the lower Rhône catchment, a high level regional strategy was devised. The "Plan Rhône" strategy aims to provide a more consistent approach to flood risk management on the lower Rhône River, identifying three main areas for improvements:
- Coordination of flood management and reduction of flood risk by better regulating development in the floodplain,

- Respecting and improving the quality of life of the inhabitants through the preservation and improvement of surface water quality and maintaining aquatic habitat biodiversity (including exploitation of these areas for cultural and social tourism),

- Ensuring a long term approach in relation to economic development.

The first theme aims to act at all levels of risk management, namely to reduce the risk of damages through limiting economic development in the floodplain to activities which are compatible with the level of risk of flooding and giving control to those facing this risk the means to respond.

As part of the strategy, new flood defence structures have been proposed for the communities currently protected by the railway embankment between Arles and Tarascon. The new flood defence scheme includes the construction of a new $9 \mathrm{~km}$ long levee structure adjacent to the existing railway embankment, with a $5 \mathrm{~km}$ section which will be resistant to overtopping. In addition, ten flood discharge structures will be constructed in the railway embankment (

Figure 3) to allow the safe transition of flood water overtopping the new levee to the floodplain to the east of the railway embankment. The system will operate during floods on the Rhône with an annual probability of $10^{-2}$ and has been designed to be resistant for floods from the Rhône with an annual probability of occurrence of $10^{-3}$ (safety level).

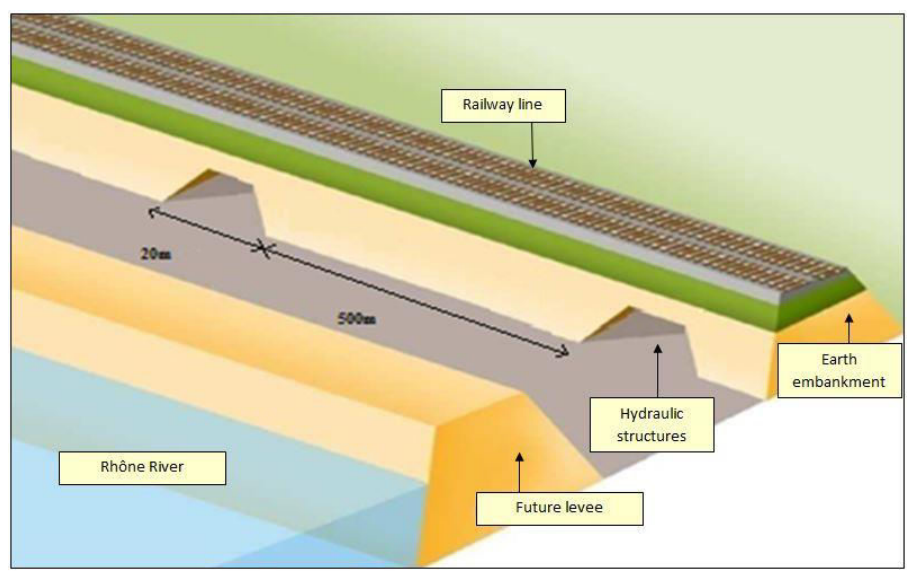

Figure 3 - New flood defence system

SNCF Réseau is responsible for the works concerning the railway embankment and a local flood defence association (SYMADREM) is co-funding and overseeing the works to construct the new levee structure. 


\section{Identifying methods for protecting the railway embankment}

Following the construction of the levee and the flood discharge structures, which is due to be completed in 2020, the existing railway embankment will be subjected to periodic hydraulic loading (floods exceeding an annual probability of occurrence of $10^{-2}$ ). As project manager for the works affecting the railway embankment, SYSTRA consultants were keen to optimize the protection of the embankment in terms of reducing costs of works whilst maintaining the high levels of security required by SNCF Réseau for the safe passage of trains.

In collaboration with Irstea and Systra, SNCF Réseau developed a four stage method to allow different scenarios of flood risk management of the railway embankment to be tested (Figure 4).

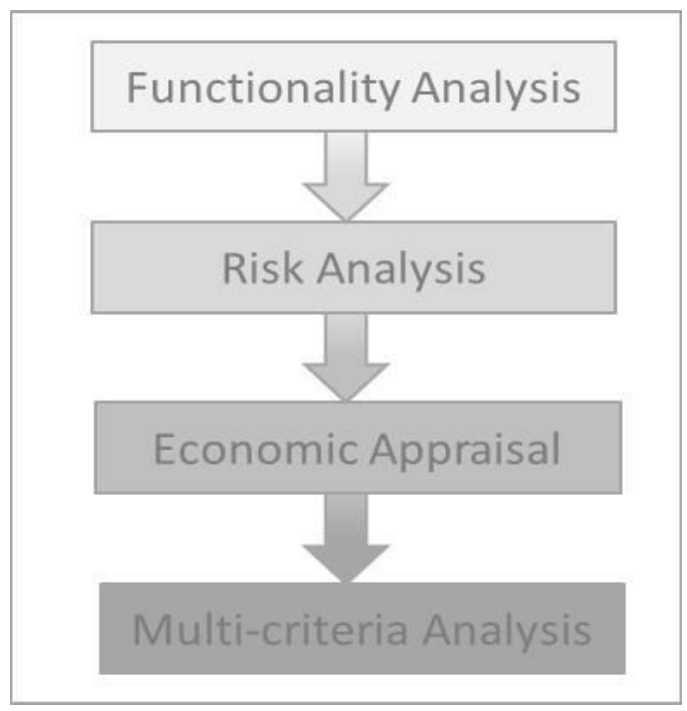

Figure 4 - Flood risk management tool

\subsection{Functionality Analysis}

The first element of the tool aims to identify the different elements of the structure providing the flood defence and evaluating their functionality ${ }^{3}$. Three levels of functionality are explored in the analysis:

-System level

-Structure level

-Sub-structure component level

The first layer of analysis allows a global understanding of the flood defence system to be made, which in the case of the current project includes the reach of the Rhône approximately $50 \mathrm{~km}$ upstream and downstream of the site. The analysis allows the role of individual flood defence structures to be understood in relation to one another in the system. Primary and secondary defences are identified as well as potential "domino effects" such as the potential of a breach in one structure affecting secondary structures in the protected area.

The second level of analysis allows the Infrastructure manager to identify the main characteristics of the flood protection structure, its sub-structure components and an overall level of protection offered by the embankment.

Once each sub-structure component within the flood defence embankment is identified, their individual functionality and efficiency to perform their role is explored in detail.

This analysis at three scales (macro to micro analysis provides a detailed understanding of the flood defence system and its potential points of weakness, which can be studied in greater detail in the risk analysis stage.

\subsection{Risk Analysis}

The detailed functionality analysis described in the previous section provides a detailed understanding of the role of each component of the railway embankment. The second stage of the approach, risk analysis, requires an evaluation to be made of the efficiency of each component to fulfil its role during periods of hydraulic loading (during overtopping of the SYMADREM spillway). This requires a detailed understanding of the main mechanisms for failure of a flood defence structure and evaluating their likelihood of occurrence. The main causes of rupture of flood defences can be grouped into six main classes:

- Overtopping (and subsequent erosion of the downstream face of the structure)

-Internal erosion (loss of material from the railway embankment itself)

-Piping (loss of material from the foundation of the railway embankment)

-Slippage (loss of stability of the embankment due to hydraulic loading/ saturation)

-External erosion of the embankment itself or the foundations of the structure

-Impact (damage to the structure from objects transported by the flood)

The understanding of the main causes of levee breach during flood conditions allows each sub-structure component of the levee to be analysed in terms of probability of non-functionality during a flood and the consequences which would result. As such, the risk analysis is based on an evaluation of risk using the relationship:

\section{Risk $=$ Probability $x$ Consequence}

The risk analysis requires a detailed knowledge of the structure including the material used in its construction, 
its geometry, the geotechnical conditions and its condition state. Much of the risk analysis for the railway embankment between Tarascon and Arles was undertaken for the detailed risk evaluation, l'Etude de dangers (EDD, reference $S N C F$ ), which was submitted to the State for evaluation in 2012. The risk analysis method developed for the EDD, considered the railway embankment in its existing configuration. This needed to be reviewed to integrate the future configuration of a new levee structure and hydraulic discharge structures beneath the railway embankment.

New detailed 2D and 3D hydraulic modelling scenarios were commissioned by Systra and undertaken by Artelia Consultants ${ }^{4}$. The results from the modelling provided detailed flooding characteristics for the zone between the new levee and the existing railway embankment. Flood depths, flow velocities and flood durations were calculated for different return period events ( 1 in 150 years to 1 in 1000 year events).

\begin{tabular}{|c|c|}
\hline $\begin{array}{c}\text { Rhône flood } \\
\text { (Return period in brackets) }\end{array}$ & $\begin{array}{c}\text { Flow overtopping the } \\
\text { SYMADREM spillway } \\
\left(\mathrm{m}^{3} / \mathrm{s}\right)\end{array}$ \\
\hline $\mathrm{Q}_{150}$ & 180 \\
$\mathrm{Q}_{250}$ & 410 \\
$\mathrm{Q}_{500}$ & 740 \\
$\mathrm{Q}_{1000}$ & 1070 \\
$\mathrm{Q}_{1000+}$ & 2260 \\
\hline
\end{tabular}

Figure 5 - Peak flows overtopping the SYMADREM spillway for different Rhône flood events

The new results allowed SNCF Réseau to evaluate the risk of damage to the railway embankment for different return period events, considering the different mechanisms for levee failure described previously (Figure 6). A detailed investigation of historical embankment failures was also used in the risk analysis including flood defence structures on the lower Rhône River (see Section 2.2).

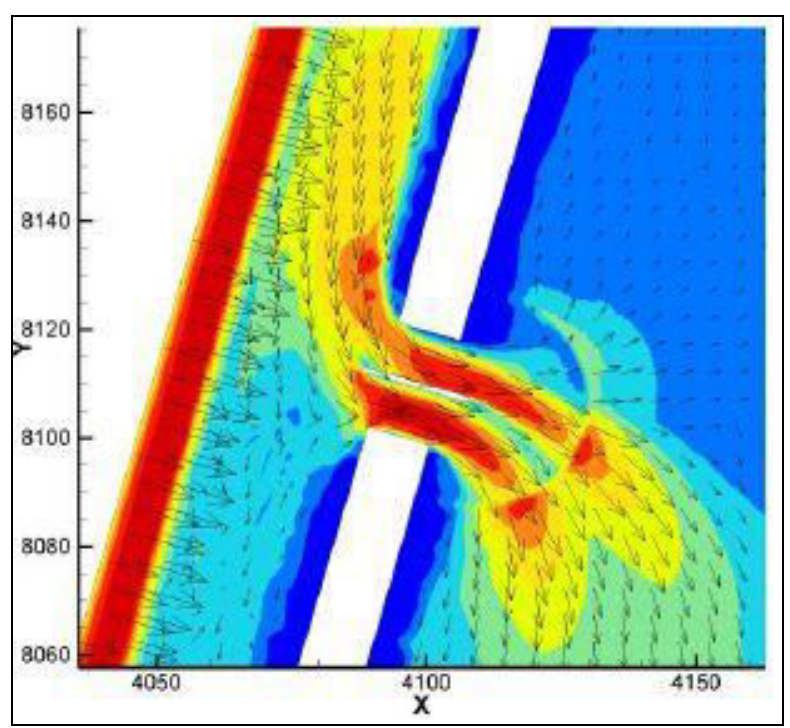

Figure 6 - Results of the 2D modelling showing flow velocities through the future flood discharge structure
The results of the risk analysis allowed certain sections of the structure to be classified in terms of low, medium and high levels of risk (breach scenario). It concluded that, of the six main mechanisms of breach indicated previously, the railway embankment would be exposed to the problem of internal and external erosion and piping, the other mechanisms having been designed out during the project conception.

\subsection{Economic Appraisal}

The economic appraisal stage allows damages to be quantified following flood events and to evaluate the efficiency of flood protection methods. The introduction of a flood protection scheme reduces the level of exposure of a structure to damage and consequently benefits the infrastructure manager through reduced repair costs or losses of normal operations. Flood protection options are compared through the calculation of the benefit/ cost ratio (and incremental cost/ benefit ratio).

In the case of the economic appraisal undertaken for the railway line between Tarascon and Arles, a key assumption was made from the outset that damages would only be considered to the railway infrastructure itself. This assumption is based on the fact that in the future, the railway embankment will not have a role of flood protection, conversely it will be 'hydraulically transparent'. Consequently, losses relating to damage to third parties (properties, industries, infrastructure) are not included in the evaluation. The damages used in the assessment include:

-Damage to the embankment infrastructure itself (foundations, earth embankment, track, signalling etc) and,

-Damages relating to loss of services during the flood event and post flooding to undertake repair works.

The economic analysis requires a life expectancy of the structure to be made (50 years in the case of the current project) and a benchmark to be set against which the options for protection are compared. The approach commonly applied in economic assessments is to fix the benchmark as the "Do Nothing" option, which sees a general degradation of the structure over time as no maintenance or structural works are undertaken. No costs are associated with this option and so no benefit/ cost ratio is calculated.

A series of flood defence options were considered with Systra and the Infrastructure manager to determine feasible methods of protecting the railway embankment. These methods provided increasing levels of protection for the railway embankment and are generally increasingly costly to implement. Through protecting the railway embankment, the level of expected damages is 
reduced for the different return period events as compared to the "Do Nothing" option. The avoided damage (or benefit) is calculated through subtracting the damages resulting post protection works as compared to the "Do Nothing" option (Figure 7).

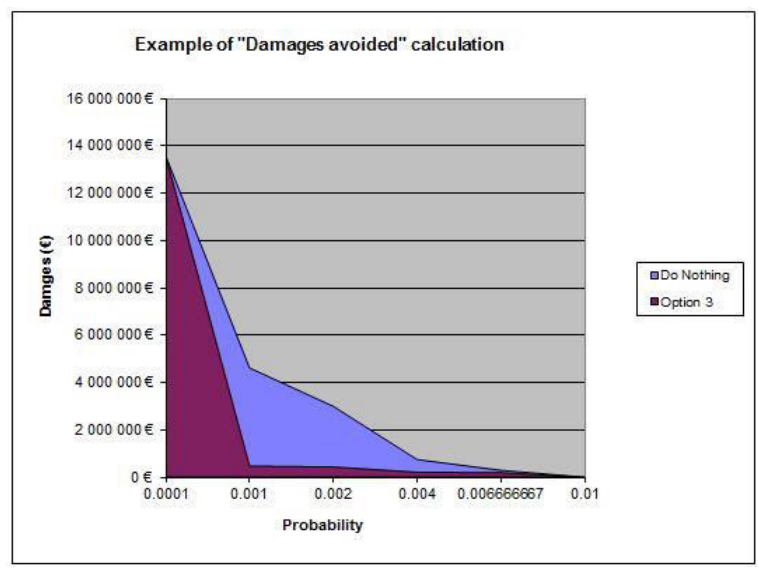

Figure 7 - Principle for comparing damages between an initial situation and one with protection works

The damages assessment for the embankment infrastructure used the results of the risk analysis including whether the damage would be sufficient to create a total breach of the railway, a partial breach (loss of a single line, or the rapid restoration of services on one of the two lines for example) or superficial damage to the embankment resulting in partial loss of services (slower train speeds over the embankment). Using the results of the risk analysis, the length of railway embankment affected by the different damages could be evaluated and typical repair costs estimated.

For damages relating to loss of services, the analysis initially considered the type of train service (Passengers, freight and other trains such as works trains), the number of each class of service, the number of passengers and the penalty costs the Infrastructure manager would suffer in the event of non-respect of the announced train services ( Figure 8).

\begin{tabular}{|l|l|}
\hline \multicolumn{1}{|c|}{ Type of train } & Penalty \\
\hline High speed train (TGV) & $22 € / \mathrm{min}$ \\
Regional express train (TER) & $13 € / \mathrm{min}$ \\
Local trains (Transilien) & $14 € / \mathrm{min}$ \\
Other long distance trains & $17 € / \mathrm{min}$ \\
Freight & $10 € / \mathrm{min}$ \\
\hline
\end{tabular}

Figure 8 : Penalties imposed on the Infrastructure manager by the rail regulator in case of non-respect of services

Alternative routes and modes of transport were also investigated as were the durations of substitution routes during the period of line closure.
There is a danger of double counting damages in the economic evaluation procedure. In order to avoid this problem, the process was undertaken in three phases considering, in decreasing levels of severity:

-Damages associated with a breach in the embankment,

-Damages associated with internal erosion to the embankment (embankment and piping)

-Superficial damages associated with external erosion

Clearly for an operational railway line, the breach scenario is the most damaging due to the long closure time to undertake repairs and the cost of providing alternative means of transport. Internal erosion of the embankment can lead to problems of settlement and subsequently track defects, a consequence which can have important impacts on the short and long term maintenance of the structure. Superficial damages include local erosion of the embankment toe which does not necessarily close the line but could lead to speed restrictions being imposed.

In addition to the baseline Option 1 - Do Nothing, seven flood protection options were considered for the railway embankment:

Option 1. Do Nothing

Option 2. Protection of the ten flood discharge structures

Option 3. Adapted planting techniques

Option 4. Waterproofing using geosynthetic (west side only)

Option 5. Waterproofing using geosynthetic on the west side and additional drainage on the east side

Option 6. Concrete lining

Option 7. Mixed system on the east side of geosynthetics and adapted planting

Option 8. Mixed system on both sides of the embankment

Figure 9 presents the solution for Option 4, waterproofing using a geosynthetic. 


\subsection{Multi-criteria Analysis}

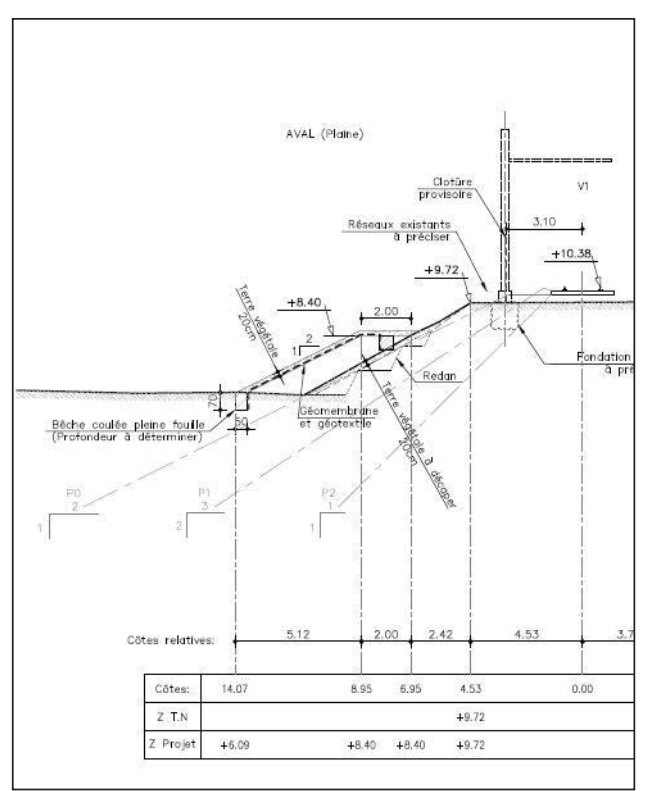

Figure 9 - Cross section of Option 3 Waterproofing using geosynthetic

Estimations for the cost of each option were based on past experience of similar projects undertaken by SNCF Réseau. Initial construction costs and maintenance costs over the 50 design life of the structure were considered.

The results of the economic analysis for the railway embankment between Tarascon and Arles showed that all of the proposed flood defence measures failed to reach a cost/ benefit ratio of 1 , most falling significantly below this threshold.

\begin{tabular}{|c|c|}
\hline Option & Cost/ benefit ratio \\
\hline Option 1 & - \\
Option 2 & 0.54 \\
Option 3 & 0.09 \\
Option 4 & 0.03 \\
Option 5 & 0.02 \\
Option 6 & 0.02 \\
Option 7 & 0.05 \\
Option 8 & 0.04 \\
\hline
\end{tabular}

Figure 10 - Summary of the Economic Appraisal

The reason for the low cost-benefit ratios obtained for the projects lies in the already high level of protection offered to the railway embankment by the future levee. No overtopping of the future levee structure is predicted below the $10^{-2}$ event. Because the damages assessment is based on the probability of exposure, the low probabilities used in the analysis means relatively low damages are calculated.
The last stage of the tool is to undertake a multi-criteria analysis, of which the economic appraisal presented in the preceding chapter plays an important role.

In the context of operating a railway line and maintaining the infrastructure, a number of benchmark indicators were deemed to be important to be used in the analysis; including security, regularity, maintenability and environmental impact.

For each indicator, a system of scoring was developed from 1 - No Impact to 5 - major impact. Each option for protecting the railway embankment was evaluated using the scoring system and a spider web diagram produced allowing the relative effectiveness of the options to be assessed (Figure 11).

The method provides a total score for each option to be calculated.

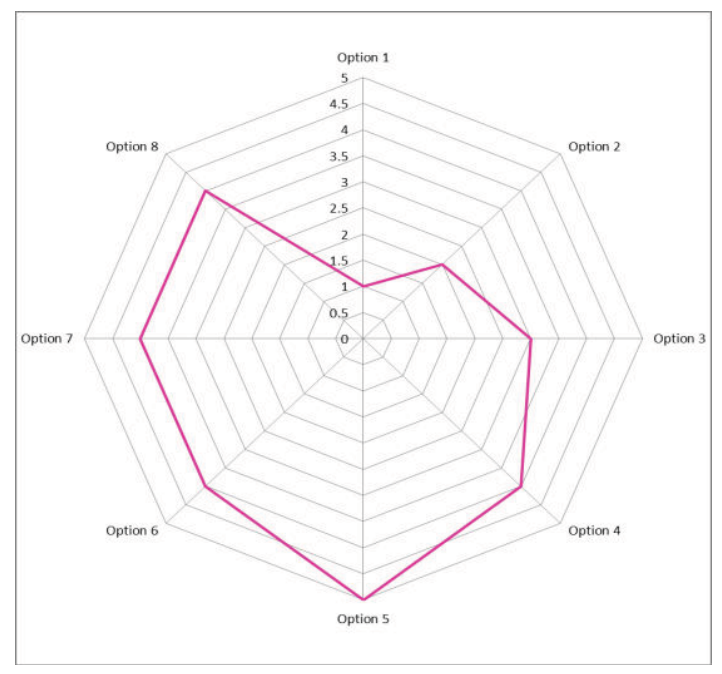

Figure 11 - Example of the spider web diagram for evaluating the relative efficiency of each option against the multi-criteria benchmark indicator.

The use of indicators allows the infrastructure manager to define strategies for flood protection based on which indicators are deemed to be of most importance (weighting). For the railway embankment between Tarascon and Arles, two possible management strategies were developed:

1. Ensure that train services can continue up to the design standard of the flood defence system (1 in 1000 years)

2. Ensure that train services can continue up to the existing level of protection offered by the railway embankment $(2 \mathrm{~m}$ below crest level of the structure). 
In the first scenario, the emphasis is placed on security of rail passengers and the reliability of the railway embankment $(60 \%$ of the total weighting is given to the indicators Security, Reliability and Availability). The second scenario places the emphasis on the economic factors (Cost/ benefit of flood protection measures) and future maintenability of the structure.

Under the two scenarios, the relatively low cost solution of protection using vegetation (Option 3) scores highly ranked second for Scenario 1 and first for Scenario 2 . The more costly solutions such as use of geosynthetics or concrete structures scored less highly, although performed well in reducing the issues relating to security (the geosynthetic option ranked in first place under Scenario 1).

\begin{tabular}{|c|c|c|c|c|}
\hline Option & \multicolumn{2}{|c|}{ Scenario 1 } & \multicolumn{2}{c|}{ Scenario 2 } \\
& Score & Ranking & Score & Ranking \\
\hline & & & 42 & 8 \\
Option 1 & 35 & 8 & 61 & 5 \\
Option 2 & 55 & 7 & 68 & 1 \\
Option 3 & 70 & 3 & 60 & 6 \\
Option 4 & 67 & 5 & 62 & 4 \\
Option 5 & 75 & 1 & 48 & 7 \\
Option 6 & 62 & 6 & 64 & 2 \\
Option 7 & 69 & 4 & 63 & 3 \\
Option 8 & 71 & 2 & \\
\hline
\end{tabular}

Figure 12 - Results of the Multi-criteria analysis

\section{Conclusions}

The method developed by SNCF Réseau, Irstea and Systra to determine appropriate and adapted flood protection measures for the railway embankment between Tarascon and Arles allowed initially a structured analysis of the functionality of the structure to be evaluated before identifying the risks associated with embankment under hydraulic loading conditions before providing the Infrastructure manager the means to make a judgement on the most efficient methods to deploy.

Through using a multi-criteria analysis, which included a detailed economic evaluation of the different flood protection measures, the Infrastructure Manager was able to adapt the method of flood protection based on different operational objectives. In both scenarios, the multicriteria analysis showed that a relatively low impact, low cost solution could be highly effective.

\section{References}

1. www.geoportail.gouv.fr

2. Consensus Conference (26-28 July 2005). Peak Discharge of the December 2003 Rhône Flood at Beaucaire

3. Felix H, Beullac B, Tourment R, Mériaux P, Peyras L (2011), Méthodologie pour l'analyse fonctionnelle des ouvrages hydrauliques à grand linéaire. CFBR/ AFEID, Etudes de dangers.

4. ARTELIA Eau \& Environnement (2014), Etude hydraulique - Tranche Optionnelle 1, BA2AVP-BEH-306-601-0006-B 